\title{
Applying UNESCO Guidelines on Mobile Learning in the South African Context: Creating an Enabling Environment through Policy
}

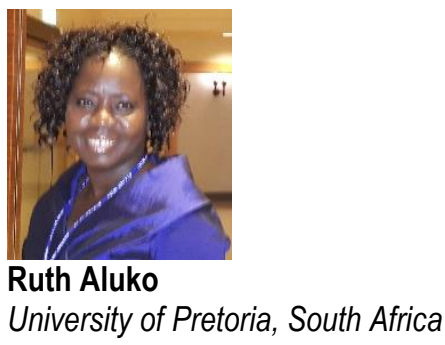

\begin{abstract}
Mobile broadband penetration is growing rapidly in Africa, and it offers vast opportunities for mobile learning. Together with its possibilities is the danger of overlooking standards related to its use. The United Nations Educational, Scientific and Cultural Organisation (UNESCO) has initiated work in this area focusing on African and Middle East (AME) countries. Countries are required to develop their own mobile learning policies. Examining information and communication technology (ICT) in the South African education environment, a qualitative approach is adopted using a literature review to assess the relevance and applicability of mobile learning in the broader education environment. A thematic analysis is used to identify themes from UNESCO's guidelines, which are compared to the South African environment. Tracing the use of technology by an open distance learning (ODL) provider, an adapted framework was developed for mobile learning. This article argues the need to create an environment that enables sustainable mobile learning provision through policy development.
\end{abstract}

Keywords: ODL, ICT, mobile learning, mobile technology, capacity building, policy

\section{Introduction}

Literature shows that mobile technology has opened up a world of opportunities for education, especially in Africa (Keegan, 2005; Traxler, 2013). Mobile learning involves the use of mobile technology, either alone or in combination with other information and communication technologies (ICTs) to enable learning anywhere, anytime (Kraut, 2013). South African mobile broadband 
penetration is reported to show the fastest growth on the continent (ITWeb Networking, 2014). Nonetheless, amid the hype about its possibilities for learning, there is a danger of over-emphasising these possibilities at the expense of quality assurance standards. Presently, the potential of mobile broadband does not necessarily appear to relate to "quality" or "policy." Scholars have often warned of the need to be cautious when adopting technologies for education (Bates, 1997; Venkatesh \& Bala, 2008; Smith \& Winthrop, 2012). This risk necessitates the need for policy statements at both governmental and institutional levels.

UNESCO has initiated work in this area by providing guidelines on the use of mobile technology for learning (Kraut, 2013). The main purpose of these guidelines, which were the outcome of a UNESCONokia partnership focusing on African and Middle East (AME) countries, is to help countries develop their own approaches to mobile learning (UNESCO, 2011). Although the guidelines are now in the public domain, the onus rests on each country to take the initiative to adapt these guidelines to its own context. Given the ubiquity of mobile technology, it appears that countries would generally have no choice but to take this step. South Africa could be said to be one of the more "advanced" countries in Africa in terms of the availability of mobile phones and bandwidth, even though it is not without its challenges. Although the country has publicly acknowledged the place of open and distance learning (ODL) in mending its education system, it has only recently enacted a policy on ODL - a delivery mode that adopts the use of technology (DHET, 2014). Towards the realisation of such a policy, this article seeks to answer the following questions:

1. What is the policy environment in South Africa regarding the use of mobile technology by ODL institutions?

2. To what extent does this relate to UNESCO's guidelines on the use of the technology?

3. How can ODL institutions (irrespective of their contexts) gauge their readiness to use mobile technology for academic purposes?

Citing the case of South Africa, this article aims to create awareness that will stimulate debate on the need to develop a policy on mobile learning in each local context based on UNESCO's guidelines.

\section{Mobile Technology: Changing the Face of Learning in South Africa}

Globally, it has been predicted that some of the key factors that will drive the expansion of mobile learning include technological advances that make mobile phones more accessible, affordable, and functional, leading to the disappearance of challenges with smaller screen size limitations and the improvement of energy sources and power capacity (Kraut, 2013). Other factors include decreasing societal resistance to using mobile phones in formal education, increasing numbers of successful mobile learning projects that can serve as exemplars for large-scale initiatives, greater pressure on educational institutions to provide high-quality education at low cost to larger numbers of students, the rise of online education and distance learning, and the cultivation of new procurement and distribution channels for digital learning resources. 
Due to the rapid growth of mobile technology in Africa, mobile penetration increased from $53 \%$ in 2012 (mobiThinking, 2015) to 75\% in 2014 (Mwenje, 2014). This has been predicted to reach 79\% by 2020, while it is asserted that some African countries have already reached saturation point. This means that every citizen has access to technology (Frost \& Sullivan, 2014). South Africa is one of the few countries in Africa with widespread access to technology (Laaser, 2006), but it is not exempted from the challenges of the digital divide: the many remote communities that remain without coverage (Gillwald, Moyo, \& Stork, 2012). Scholars have called for caution in inferring vigorous future growth for mobile communications due to demographic and related economic aspects (Balancing-act Africa, 2017).

In South Africa, while not all schools have the capacity to integrate ICTs into classrooms, a growing range of mobile offerings, including applications (apps) and curriculum-supporting websites, is changing the way students interact with learning material (Ngubeni, 2014). In Africa, far from being a theoretical possibility, mobile learning is a current reality (Kraut, 2013). However, scholars have cautioned that ICTs have no intrinsic benefits per se, but are most usefully understood when they are interwoven into practices that exist in specific contexts and for particular purposes (Vosloo, 2013; Kirkwood \& Price, 2006). Nonetheless, the unique benefits of mobile learning include its ability to facilitate personalised learning anytime, anywhere, build new communities of learners, and assist learners with disabilities (Kraut, 2013). Mobile technologies have replaced different tools on which people can learn, such as desktop computers, daily newspapers, DVDs, college backpacks, and pocket foreign language dictionaries (Mims, 2012; Qualman, 2016), some of which are not even available to students in rural communities.

In Africa, the use of ICTs in pedagogy is undermined by the misalignment between either enacted or espoused policy (where it exists) on the one hand, and infrastructure, insufficient human resources, poor connectivity, and a lack of access on the other (Tamukong, 2007; Muwanga, 2009). This article focuses on the need to create an environment for sustainable mobile learning provision through policy development.

A policy is an official, formalised plan or course of action that serves to guide and determine decisions, actions, and good practice. Although many African countries appear to have ICT policies, there is a general and marked absence of policies dedicated to mobile learning (Tamukong, 2007). Scholars have attributed this absence to the ignorance of policy makers regarding the capabilities of mobile technologies, negative perceptions that some have about mobile learning, limited examples of sustainable and scalable projects, and issues related to digital access rights, including censorship and privacy concerns (Kraut, 2013). Due to its interwoven nature, capacity building has been identified as a useful method to confront the many challenges involved in ICT usage in Africa (Tamukong, 2007). One way to create an enabling environment at the organisational level is to develop policies that allow organisations to operate optimally and deliver on their mandates (UNDP, 2009).

\section{Research Design and Data Analysis}

This study adopted the qualitative research design, in which literature and ICT-related documents were analysed. UNESCO's policy suggestions were juxtaposed with identified documents in South 
Africa. The goal was to analyse the documents thematically. Thematic analysis is a qualitative method to identify, analyse, and report patterns within data, which do not need to be tied to any pre-existing theoretical framework (Braun \& Clarke, 2006). This article is based on the inductive "bottom up" thematic analysis approach, in which identified themes are linked to the data (Patton, 1990; Frith \& Gleeson, 2004; Braun \& Clarke, 2006) and not to any pre-existing coding frame (Braun \& Clarke, 2006). Thus, the themes have only been identified at the semantic level, in which the researcher is only interested in surface meaning (Braun \& Clarke, 2006; Boyatzis, 1998). This enabled a description, comparison, and explanation of the findings (Ryan \& Bernard, 2003).

The study made use of the six phases suggested by Braun and Clarke (2006):

Phase 1: Familiarising oneself with the data through repeated reading: This involves immersing oneself in the data by repeatedly reading it in an active way to become familiar with meanings and patterns. This process involves taking notes and marking ideas for coding.

Phase 2: Generalising initial codes: This involves generating initial codes from the data based on the identified meanings and patterns identified in Phase 1. In this case, the coding was done manually as the researcher did not peruse too many documents.

Phase 3: Searching for themes by sorting codes into potential themes: This involves re-focusing the analysis at the broader level of themes rather than codes. In this phase, the different codes are sorted into potential themes. This enabled the researcher to identify the relationship between codes and themes.

Phase 4: Reviewing the themes for refinement: In this phase, the researcher was able to consolidate some themes to avoid repetition. This phase also enabled her to consider the validity of individual themes in relation to the data set.

Phase 5: Defining and naming themes: This involves further refining the themes, which enables one to identify the essence of each theme given the overall picture.

Phase 6: Producing a report: This involves documenting the findings of the research, which are written in such a way as to go beyond a mere description of the data. The argument is stated in relation to the research questions.

\section{Research Findings}

The research findings have been divided between the identified documents in the ICT policy environment and mobile learning in South Africa, and the identified themes in UNESCO's Policy Guidelines for Mobile Learning (Kraut, 2013). The application of these findings to the research questions is then discussed.

\section{Identified Documents in the ICT Policy Environment and Mobile Learning in South Africa}


Research shows that almost all African countries have ICT policies in place (Farrell \& Isaacs, 2007; IST-Africa, 2012; Kraut, 2013) and giant strides are being made. In South Africa, the current policy framework for ICT in education has been evolving since 1996. It is embedded within government's broader economic, social, and development strategy (Isaacs, 2007). Three documents in particular relate to the policy environment in terms of mobile learning in South Africa:

\section{- National Association of Distance Education Organisations of South Africa} (NADEOSA) quality criteria (Welch \& Reed, 2005): This document was initially developed in the course of research undertaken for the Department of Education (DoE). The quality criteria have since been revised through a stakeholder process involving the distance education community. The criteria include policy and planning, learners, programme development, course design, course materials, assessment, learner support, human resource strategy, management and administration, collaborative relationships, quality assurance, information dissemination, and results.

- Policy for the Provision of Distance Education in South African Universities in the Context of an Integrated Post-school System (DHET, 2014): Although South Africa has been involved in distance education for over a century, it has only recently launched its policy on the model. An important factor to have influenced the policy is the ubiquitous penetration and affordability of ICT across the country. One of the key provisions of the policy statement is the creation of an enabling environment for the appropriate integration of ICT to enhance distance education provision in both public and private universities, as well as other post-schooling institutions.

- Distance Higher Education Programmes in a Digital Era: Good Practice Guide (Council on Higher Education [CHE], 2014): This guide was developed through a consultative process by the South African Institute for Distance Education. It provides good practice guidelines, examples and indicators for the development and evaluation of distance education programmes, including those supported by digital technologies. Some of its key components include the consideration of the impact of technology, the evaluation of distance education provision in a digital era, and lines of enquiry to guide programme developers and evaluators.

Of the three documents mentioned above, only the second is an enacted policy that has gone through a proper legislative process. The other two are espoused policies that show stakeholders' recognition of the affordability that mobile technology could bring to education.

\section{Identified Themes in UNESCO's Policy Guidelines for Mobile Learning}

The policy guidelines on mobile learning emanated from UNESCO's attempt to discuss the opportunity for a set of policy guidelines that could help countries develop their own approaches to mobile learning (UNESCO, 2011). The guidelines illuminate ways in which mobile technologies can be used to support the United Nations' "Education for All" goals, while responding to the challenges of particular educational contexts, supplementing and enriching formal schooling, and making learning more accessible, equitable, personalised, and flexible for students everywhere (Isaacs, 2012).

The following 10 policy guidelines are discussed in the document: 
1. Create or update policies related to mobile learning.

2. Train teachers to advance learning through mobile technologies.

3. Provide support and training to teachers through mobile technologies.

4. Create and optimise educational content for use on mobile devices.

5. Ensure gender equality for mobile students.

6. Expand and improve connectivity options while ensuring equity.

7. Develop strategies to provide equal access for all.

8. Promote the safe, responsible and healthy use of mobile technologies.

9. Use mobile technology to improve communication and education management.

10. Raise awareness of mobile learning through advocacy, leadership, and dialogue.

Based on the six phases of thematic analysis identified by Braun and Clarke (2006), 10 themes have been identified from UNESCO’s guidelines (see Figure 1).

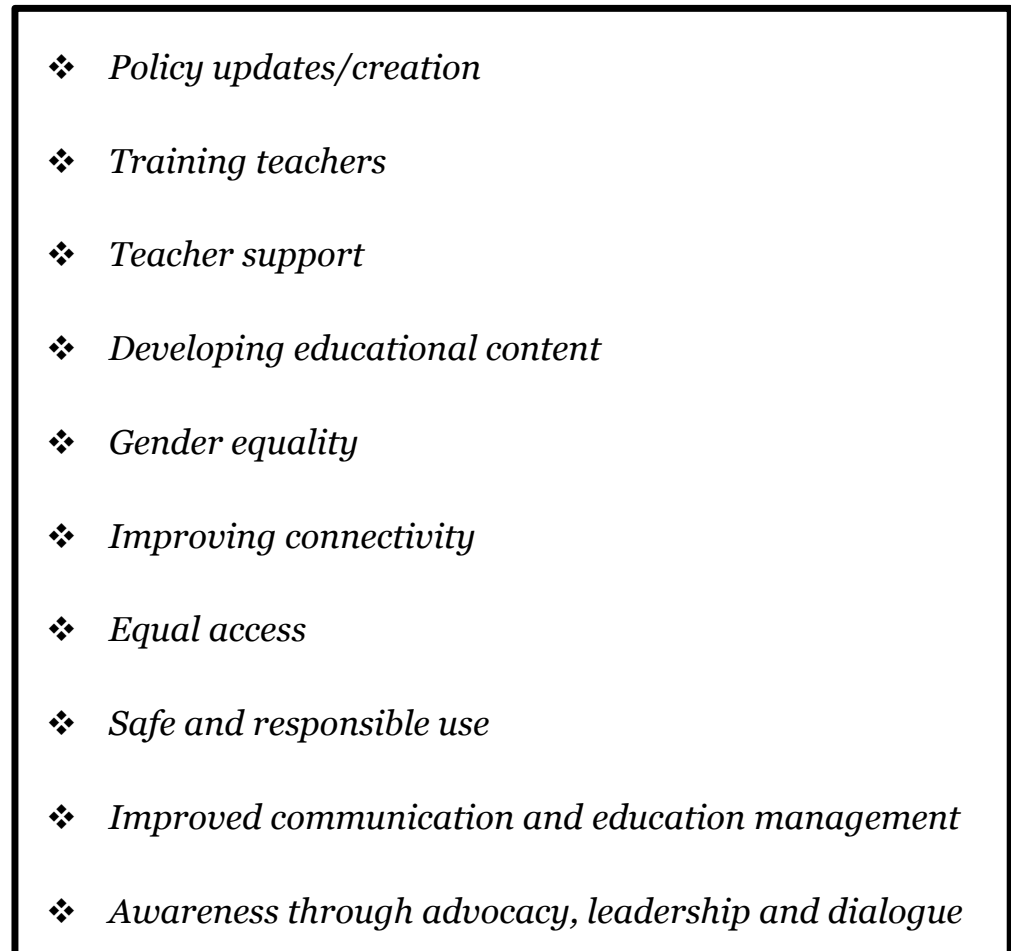

Figure 1. The 10 themes identified from UNESCO's guidelines, based on the six phases of thematic analysis identified by Braun and Clarke (2006).

The essence of this research is to identify similarities between UNESCO's guidelines and the South African context, to identify gaps and to make recommendations. This enabled the researcher to 
rigorously apply the themes to make her assumptions congruent with the way she has conceptualised the subject matter (Reicher \& Taylor, 2005; Braun \& Clarke, 2006).

\section{Discussion}

\section{Assessing the South African Mobile Technology-in-Education Environment}

The themes from UNESCO's policy guidelines for mobile learning have been used to assess South Africa's mobile technology-in-education environment. Due to their interrelatedness, overlapping themes have been combined to avoid unnecessary repetition. This is in line with the Phase 4 of the process described by Braun and Clarke (2006).

Policy updates and awareness through advocacy, leadership, and dialogue. Two of UNESCO's policy guidelines relate to the theme of policy updates and awareness through advocacy, leadership and dialogue. These are the guidelines: create or update policies related to mobile learning and raise awareness of mobile learning through advocacy, leadership and dialogue (see Figure 1).

Although mobile technology holds significant potential for resolving AME countries' educational challenges, mobile learning has to be supported by political will and leadership (Isaacs, 2012). The three documents that were compared to UNESCO's policy guidelines provide evidence of South Africa's ongoing effort to update its ICT policies, provide leadership, and create awareness of the importance of technology and its relevance to education. Even though there is not yet a fully dedicated policy on mobile learning in the country, government seems to be aware of the affordability that mobile technology could bring to ODL. Furthermore, there is ample evidence that all the policy and policy-related documents have been developed through dialogue and consultation. There is also evidence that these efforts have filtered down to institutions of higher learning, since most of these institutions have developed policies on the use of ICTs to enhance student learning. However, the findings reveal that the first two documents-NADEOSA's Quality Criteria and the Policy for the Provision of Distance Education in South African Universities (DHET, 2014)-merely allude to the potential use of technology for learning; Good Practice Guide of the Council on Higher Education (CHE) provides only a general guide on the use of ICTs. The country therefore does not appear to have a dedicated policy on mobile learning. This fact supports findings from literature that there is a policy vacuum regarding the use of the technology in AME countries (Keating \& Williams, 2006; (Isaacs, 2012).

Training and supporting teachers. Another two of UNESCO's policy guidelines-train teachers to advance learning through mobile technologies and provide support and training to teachers through mobile technologies-relate specifically to the training and support of teachers (see Figure 1).

Teachers are crucial to any expected success with mobile learning. However, without proper training and support, teachers are in danger of using ICTs to merely transmit subject content, rather than to truly take advantage of these technologies to enhance learning (Ndlovu \& Lawrence, 2012). This occurs because many teachers grew up in environments with limited electronic technology, and thus 
find the adaptation necessary for working with ICTs more difficult than their learners do. Hence, there is a need for extensive staff development and support (DoE, 2004).

Initiatives in collaboration with government involve organisations such as the Meraka Institute, Microsoft, and Vodacom. The Vodacom Mobile Education Programme focuses especially on Mathematics and Physical Science (Brand South Africa, 2011). The training focuses on ICT literacy, as well as the effective use and integration of digital content in the classroom. To support this training, educators are provided with the necessary ICT infrastructure and tools. Although research-based evidence that mobile phones can enhance and support teachers' professional development and ODL is sparse in AME countries, a range of projects has shown that Short Message Service (SMS) technology can facilitate communication with student teachers in remote areas. It has also shown that technology can serve as a curriculum delivery platform, support education management and information systems, and enable peer support, teacher training and continuing teacher professional development (UNESCO, 2012a). At the higher education level, institutions are continually making efforts to train and update the ICT skills of staff and students.

Creating and optimising educational content. A further one of UNESCO's policy guidelines relates to the need to create and optimise educational content. This is the guideline: create and optimise educational content for use on mobile devices (see Figure 1).

Research shows that South Africa is the leading innovator in Africa in terms of social networking, microblogging, and content creation (UNICEF, 2012). South African researchers are extensively involved in UNESCO's work in mobile learning (UNESCO, 2011). The government-in partnership with the relevant companies-has been involved in the content development of interactive workbooks (Mnisi, 2015). In 2013, for example, Future Mobile Technology launched a tablet pre-loaded with South Africa's Mathematics and Physical Science curricula for grades 10 to 12 (Future Mobile Technology, 2013). The country has also made giant strides in the development of home-grown instant messaging services, such as MXit.

Examples of successful educational projects on MXit are Dr Math, a project that helps school learners with their Mathematics homework via their cell phones (Butgereit, 2007), and Yoza, a research project that has evolved into an online library of mobile novels and short stories ((Isaacs, 2012). Other examples from the continent are the BridgeIT initiative in Tanzania and the Dunia Moja project in South Africa, Tanzania, and Uganda, in partnership with Stanford University in the USA (Trucano, 2009). Some instructional design guidelines based on a solid theoretical framework for mobile learning exist (Traxler, 2009; Isaacs, 2012; Park, 2014). Nevertheless, scholars indicate that more academic research is needed on the app (Chigona \& Chigona, 2008; Makoe, 2010; Mayisela, 2013). More research is also necessary to categorise the numerous examples of mobile learning in the context of distance education.

Equal access and gender equality. Another two of UNESCO's policy guidelines-ensure gender equality for mobile students and develop strategies to provide equal access for all-relate specifically to the need for equal access and gender equality in the adoption of mobile learning (see Figure 3). 
Even though some landmarks have been achieved, a lot still needs to be done with regard to gender equality in terms of mobile technology. According to a recent study by the Global System Mobile Association (2015), over 1.7 billion females do not own mobile phones. Cost remains the greatest barrier. This is because women from such backgrounds typically have less financial independence than men. The challenge is not only limited to the cost of the handset, but also the use and maintenance of handsets or related equipment (Isaacs, 2012).

Earlier in one of its studies, Isaacs (2012) gave other possible reasons as a combination of unequal distribution of income, restrictive social taboos, and higher illiteracy rates among women. However, in South Africa, the reverse is the case as female mobile subscribers tend to outnumber males (Gillwald et al., 2012). Nonetheless, South Africa is not without its challenges as most subscribers are located in urban areas. Some efforts are being made to address the issue of connectivity through diverse governmental and non-governmental projects.

Improved communication and education management. Another two of UNESCO's policy guidelines-expand and improve connectivity options while ensuring equity and use mobile technology to improve communication and education management-relate specifically to the need for improved communication and education management (see Figure 3).

The availability of more bandwidth has led to improved communication and education management in the country. ICTs have the capacity to automate processes and save time, which frees managers to focus on instructional leadership (DoE, 2004). Many mobile apps for better classroom management are available (Educational Technology and Mobile Learning, 2015). Many ODL providers are also using mobile technology extensively for administrative and management purposes (CHE, 2014; Aluko \& Hendrikz, 2012).

Safe and responsible use. A further one of UNESCO's policy guidelines relates to the safe and responsible use of mobile technologies for learning. This is the guideline: promote the safe, responsible and healthy use of mobile technologies (see Figure 3).

Concerns regarding safety and the responsible use of ICTs are widespread and serious. This is because of the dangers to which users, especially children, are exposed. In a study conducted by the United Nations Children's Fund (UNICEF) on South African youths on mobiles (UNICEF, 2012), the primary risks faced by adolescents and young people online were talking to and meeting strangers, cyber bullying, and sexting. These risks have led to the most popular social network developed in the country (MXit) acquiring a bad reputation, despite its potential academic value (Chigona, Chigona, Ngqokelela, \& Mpofu, 2009). Unfortunately, in most African countries, no coordinated activities in this regard are taking place, even though many children are already active in cyber space (Von Solms \& Von Solms, 2014). The risks of ICT use relate to content, contact, and conduct, and are often determined by behaviours rather than the technologies themselves (Byron, 2008).

The South African government has compiled a set of e-safety guidelines to identify the different ICTs currently used by school communities, in particular by teachers and learners, and to recommend strategies for managing ICTs to determine their appropriate and optimal use in education (Department of Basic Education [DBE], 2012). Based on this, schools are expected to develop an Acceptable Use Policy (AUP) that covers different media platforms, most of which are available on 
mobile devices. At the higher education level, institutions provide students and staff with appropriate "netiquette" guidelines for the use of ICTs. Scholars have recommended identifying and educating all stakeholders in the cyber safety of children (DBE, 2012), including the introduction of cyber safety curricula in schools (Von Solms \& Von Solms, 2014). Nonetheless, the lack of a dedicated policy on mobile learning seems to indicate that matters have been left in the hands of individual ODL providers (UNICEF, 2012).

\section{Contextualisation of UNESCO's Suggestions}

In order to contextualise UNESCO's suggestions, the use of mobile technology by an ODL provider has been traced. The aim is to develop an adapted framework to assess ODL providers' readiness to adopt mobile learning. According to UNESCO (2013), one of the reasons for its suggestions on the adoption of mobile learning is to support the "Education for All" goals in order to respond to the challenges of particular educational contexts. Therefore, one hopes that relevant stakeholders will find the framework useful and that they can adapt it to each context.

The use of mobile technology by an ODL provider. Distance education programmes at the University of Pretoria are only offered in the Faculty of Education. These programmes are geared towards assisting teachers who were seriously disadvantaged during the apartheid era. Most of these teachers are employed in predominantly rural areas.

Figure 1 provides a broad overview of the evolution of the use of technology in distance education programmes. The distance education initiative was launched in 2002 with the initial intention of running paper-based programmes, supported by online delivery, because of the capacity of the University's technological infrastructure. Figure 1 also shows that this vision was redefined, because very few students had internet access (1\% in 2002 and $3 \%$ in 2003). However, this has gradually changed over the years (reaching $29 \%$ in 2014). Therefore, the University decided to explore possibilities for augmenting the traditional paper-based delivery mode with SMS technology. Initially, SMS was used largely as a tool for administrative support, reminding students of important events such as tutorials, assignment deadlines and examination dates, and providing tracking numbers for parcels dispatched. 


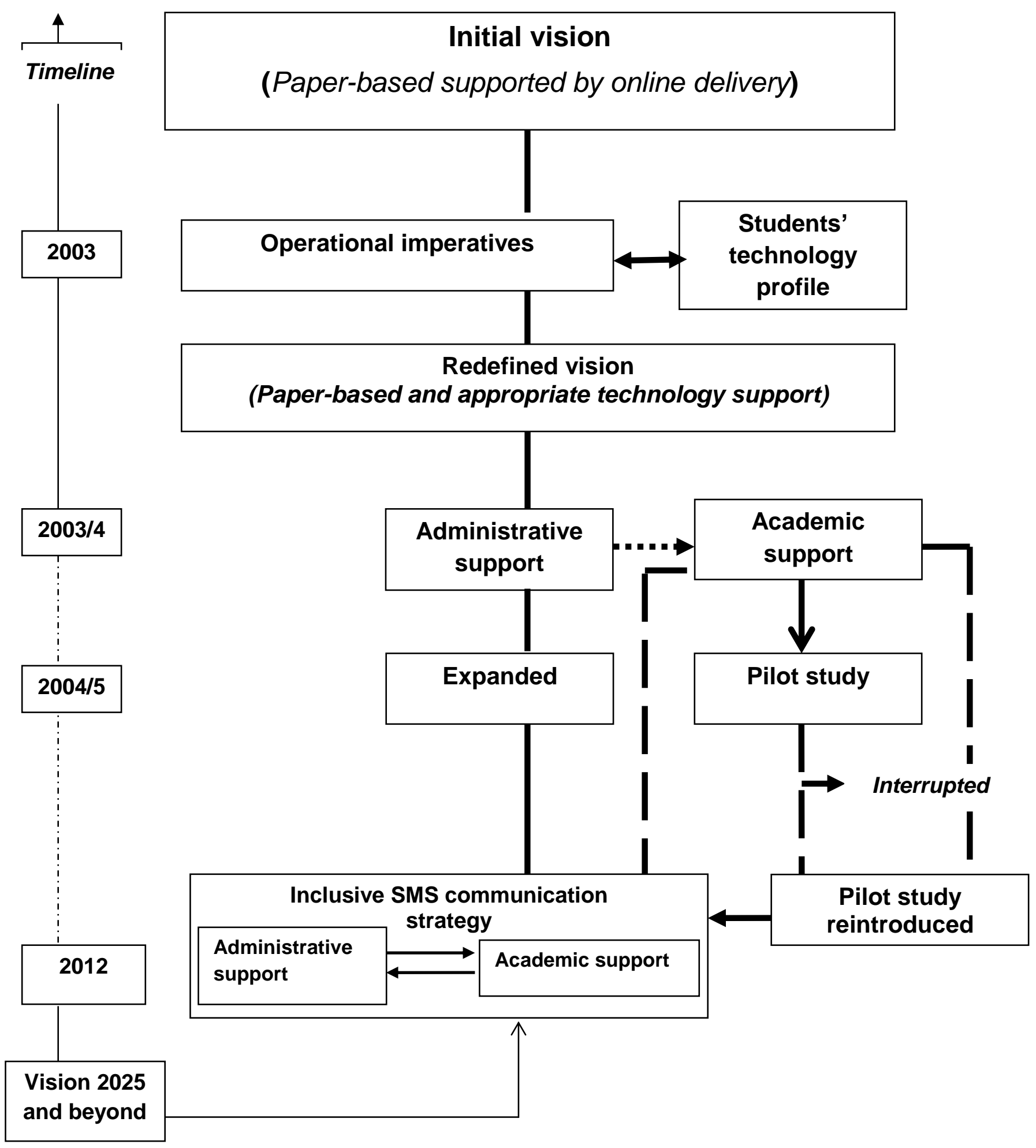

Figure 2. Development of the use of SMS for distance education students at the University of Pretoria. Adapted from Educational technology changes in Africa and its impact on ODL programmes delivery: the case of the University of Pretoria, South Africa, (page 10) by J. Hendrikz and F. R. Aluko, 2013. Copyright by ICDE 2013 World Conference. Adapted with permission. 
The expansion of SMS use for administrative support prompted the University to think of innovative ways of extending the same facility to include academic support. The University piloted this expanded function for a while. Its purpose was to mimic what a lecturer does in a conventional face-to-face learning encounter and to translate that into an SMS to support distant students academically. Findings from the studies showed that it is possible and advantageous to use SMS technology to support students academically, albeit in a limited way (Viljoen, Du Preez \& Cook, 2005; Aluko \& Hendrikz, 2012). Despite the findings, the implementation of the project was interrupted by a number of factors, including staff turnover and a lack of interest on the part of academics using technology in this way.

Experiences at the University of Pretoria have, so far, shown that the interactive nature of both an administrative and an academic SMS leads to the blurring of boundaries between the impact of both the academic and the administrative SMS on students' learning (Hendrikz \& Aluko, 2013). Presently, in alignment with the University's strategic plan, the Unit for Distance Education is exploring ways of presenting its programmes via the same medium, focusing more on mobile technology due to its ubiquity. Due to this focus, more training sessions with adequate support are being provided for academics. There appears to be a change in attitude and more interest towards the adoption of mobile learning.

\section{A Framework to Assess ODL Providers' Readiness to Adopt Mobile Learning}

According to the researcher's own experience and evidence from literature (UNESCO, 2012b; Makoe, 2010), a framework is presented that justifies the possible use of SMS technology to support distance education students academically. This framework is informed by UNESCO's policy guidelines (Kraut, 2013) and has been adapted from NADEOSA's quality criteria (See Figure 3 , Welch \& Reed, 2005). 
1. Does the institution demonstrate processes and ongoing efforts to improve the quality of teaching and learning with regard to technology available to students through monitoring and evaluation processes?

2. Has the institution conducted a careful analysis of the most appropriate technology?

3. Does the technology meet the demands of cost-effective educational provision?

4. Is the selection based on the needs, resources and capabilities of the students and institutions?

5. Does it create equal educational opportunities for students?

6. Do students have sufficient access to the technology to succeed?

7. Does the technology provide for true two-way communication?

8. Does the management of the institution support the adoption of the technology?

9. Do staff development programmes equip staff to perform their roles and tasks effectively?

10. Does the institution have a policy in place with regard to the safe use of the technology?

11. Does the institution have a monitoring and evaluation plan in place to assess the impact of the technology on students' learning and performance?

12. To what extent are staff members, learners and other clients involved in the processes of quality assurance?

Figure 3. Framework for the Use of Mobile Technology for Teaching and Learning based on the NADEOSA's quality criteria for designing and delivering distance education identified by Welch and Reed (2005).

The link between the themes identified in UNESCO's guidelines and the adapted framework. A cursory look at Figure 3 shows that most of the aspects of the adapted framework are closely linked to UNESCO's suggestions. There are also some overlapping themes; however, fitting some aspects of the adapted framework into the policy guidelines poses some difficulties. 


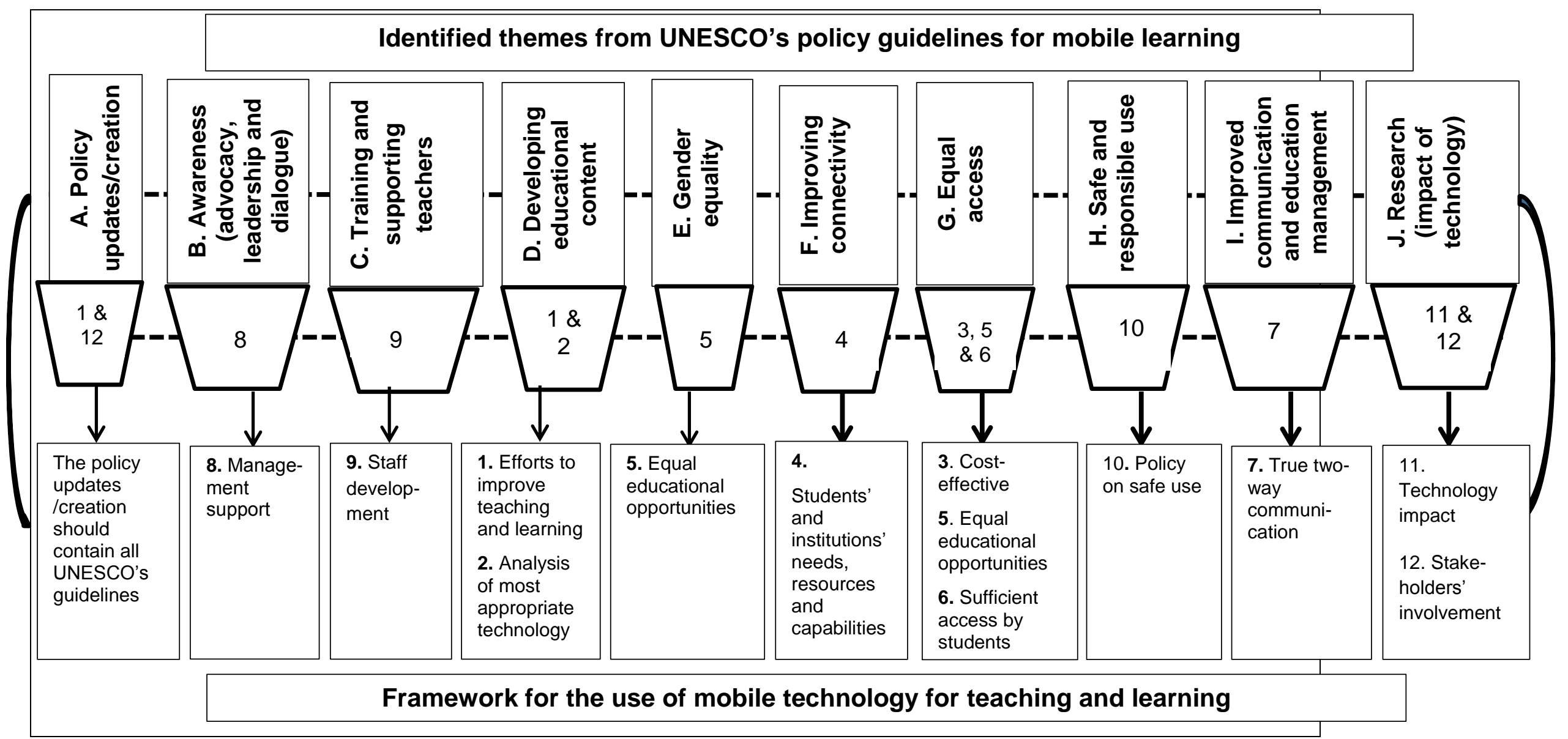

Figure 4. Integration between identified themes from UNESCO's policy guidelines and framework for the use of mobile technology for teaching and learning. 
In relation to Figure 4, before one can talk of policy updates as indicated in UNESCO's policy guidelines, there should first be a policy in place on the use of the technology. This should lead to policy creation in the absence of none. The policy should then contain all of UNESCO's guidelines, which could be regularly updated as the need arises. Although mentioned in various UNESCO research projects (Isaacs, 2012), it is necessary to clearly state the need for a monitoring and evaluation process in each country's policy to monitor the impact of the technology on students' performance. All stakeholders should be involved in the quality assurance process. If this is not done, it tends to become a nice-to-have technology; the end needs to justify the means. This would also help alleviate the frustrations of policy makers with regard to the shortage of evidence-based research on and empirical evidence of mobile learning (Isaacs, 2012). The issue of cost-effective educational provision should also be examined and clearly stated. All these "missing links" should be clearly stated in the policy documents of all countries (and institutions) that would like to adopt mobile technology for learning. For an effective policy environment, it is necessary to avoid assumptions.

Lastly, ODL providers (irrespective of their contexts) need to provide sincere answers to the questions posed in the adapted framework for the use of mobile technology for teaching and learning (see Figure 3). This should be based on the continuous tracking of the technology profiles of their students, the providers' ability to meet students' technology needs and the technical know-how of their staff members (among others), before adopting the technology for teaching and learning.

\section{Conclusion and Recommendations}

Despite the hype around the possibilities of mobile technology for teaching and learning, quality assurance standards related to its use might be overlooked. This paper considers UNESCO's suggested guidelines on the adoption of mobile learning in relation to the South African policy environment. Findings have revealed that the country has been sensitive to the potential of this technology for some decades. This is evident from the documents perused. However, these documents are focused on the use of ICTs for teaching and learning in general. Although South Africa could be said to be more advanced with regard to mobile learning than many other African countries, findings reveal that South Africa, like most African countries, does not have a dedicated policy on mobile learning. In most instances, it seems that regulations for the use of this technology are left in the hands of individual providers (UNICEF, 2012). One of the ways in which an enabling environment could be created is to develop policies that ensure delivery on mandates. Therefore, it seems that a policy vacuum needs to be filled.

In order to encourage debate in this field, the use of the technology by an ODL provider has been traced and an adapted framework is suggested. Although the quality criteria indicated in Table 2 is neither comprehensive enough nor interpreted in the same way by different institutions (Welch \& Reed, 2005), it is felt that they might go a long way in stimulating debate among ODL providers. This will hopefully develop into a policy for practice. It is believed that ODL providers could build on the suggested framework, irrespective of the context, especially when considering the constant changes that occur within the mobile technology environment. 
ODL providers need to adopt the common sense approach in the use of mobile technology. If stakeholders could achieve this understanding from the onset, the adoption of educational technologies would become more relevant to their contexts, within their financial reach, and more sustainable in terms of the availability of relevant local human and technical resources. This would, in turn, not jeopardise the essence of capacity building to groom the home-based support of organisations that sponsor projects and thereby support governments. It is argued that most of UNESCO's suggestions are based on sound and prudent judgement and could be applied after an analysis of each context. Due to the immense value that mobile technology could add to education, one could argue that having a policy in place would go a long way in sustaining both research and funded projects, with benefits also accruing to the funders.

Having a national policy on mobile e-learning in place has the tendency to encourage government ministries and agencies to be involved in projects. It is also beneficial to link projects to the national school curriculum. Projects should not be left to gather dust, but teachers and students should be supported to encourage their active participation. Finally, it would be in the best interest of countries to encourage the local development of cheaper learning platforms to make such more available to their citizenry irrespective of the gender.

\section{References}

Aluko, F.R., \& Hendrikz, J. (2012). Supporting distance education students: the pilot study of a tutorial model and its impact on students' performance. Progressio, 34(2), 68-83. Retrieved from https://journals.co.za/content/progress/34/2/EJC130289

Balancing-act Africa. (2017). Are mobile phone penetration rates in Sub-Saharan Africa really as low as they seem? Retrieved from http://www.balancingact-africa.com/news/telecomsen/21004/are-mobile-phone-penetration-rates-in-sub-saharan-africa-really-as-low-as-theyseem

Bates, A.W. (1997). The impact of technological change on open and distance learning. Distance Education, 18(1), 93-109. Retrieved from http://www.tandfonline.com/doi/abs/10.1080/0158791970180108\#.UbA6rNJHJic

Boyatzis, R.E. (1998). Transforming qualitative information: Thematic analysis and code development. Thousand Oaks, CA, London and New Delhi: Sage.

Brand South Africa. (2011). Mobile technology for better teaching [Blog post]. Retrieved from https://www.brandsouthafrica.com/governance/education/vodamobile-241011

Braun, V., \& Clarke, V. (2006). Using thematic analysis in psychology. Qualitative Research in Psychology, 3(2), 77-101. Retrieved from http://www.informaworld.com/smpp/content $\sim \mathrm{db}=\mathrm{all} \sim \operatorname{content}=\mathrm{a} 795127197 \sim$ frm $=$ titlelink 
Broadband stats 2014. (2014). Retrieved from http://www.itweb.co.za

Butgereit, L. (2007, April). Math on MXit as a medium for Maths education. Meraka Innovative Conference for Educators, CSIR, Pretoria.

Byron, T. (2008). Safer children in a digital world. Byron Review. Retrieved from http://webarchive.nationalarchives.gov.uk/20130401151715/https://www.education.gov.uk/ publications/eOrderingDownload/DCSF-00334-2008.pdf

Chigona, A., \& Chigona, W. (2008). MXit up in the media: Media discourse analysis on a mobile instant messaging system. The South African Journal of Information and Communication, 9. Retrieved from www.sajic.org.za/index.php/SAJIC

Chigona, A., Chigona, W., Ngqokelela, B., \& Mpofu, S. (2009). MXit: uses, perceptions and selfjustifications. Journal of Information Technology and Organizations, 4. Retrieved from http://www.mobileactive.org/files/file_uploads/JIITOv4poo1-016Chigona369.pdf

Council on Higher Education (CHE). (2014). Distance higher education programmes in a digital era: good practice guide. Pretoria: CHE.

Department of Basic Education (DBE). (2012). Implementation strategy for e-education in South Africa (2013-2025) [PowerPoint presentation]. Retrieved from http://www.bridge.org.za/wp-content/uploads/2014/12/ICTs-DBE\%E2\%80\%99s-New-EEducation-Strategy-Presentation-Nov-2012.pdf

Department of Education (DoE). (2004). White paper on e-Education. Pretoria: DoE.

Department of Higher Education and Training (DHET). (2014). Policy for the provision of distance education in South African universities in the context of an integrated post-school system [Government notice]. Retrieved from http://www.gov.za/ss/documents/higher-educationact-policy-provision-distance-education-south-african-universities

Educational Technology and Mobile Learning. (2015). 6 iPads for better classroom management [Blog post]. Retrieved from http://www.educatorstechnology.com/2013/06/6-ipad-apps-forbetter-classroom.html

Farrell, G., \& Isaacs, S. (2007). Survey of ICT and education in Africa. Washington, DC: infoDev/World Bank. Retrieved from http://www.infodev.org/en/ Publication.353.html

Frith, H., \& Gleeson, K. (2004). Clothing and embodiment: Men managing body image and appearance. Psychology of Men and Masculinity, 5(1), 40-48.

Frost \& Sullivan. (2014). Mobile connectivity and growing data services drive the telecoms market in Africa [Blog post]. Retrieved from http://ww2.frost.com/news/press-releases/frost-sullivanmobile-connectivity-and-growing-data-services-drive-telecoms-market-africa/ 
Future Mobile Technology. (2013). SA company in world first in mobile education (Blog post). Retrieved from http://www.itweb.co.za/index.php?option=com content\&view=article\&id=68957\#prcontact $\underline{\mathrm{S}}$

Gillwald, A., Moyo, M., \& Stork, C. (2012). Understanding what is happening in ICT in South Africa: A supply- and demand side analysis of the ICT sector. (Research ICT Africa policy paper 7, 2012). Canada: International Development Research Centre. Retrieved from https://www.researchictafrica.net/publications/Evidence_for_ICT_Policy_Action/Policy_Pa per 7 - Understanding what is happening in ICT in South Africa.pdf

Global System Mobile Association (GSMA). (2015). Bridging the gender gap: Mobile access and usage in low and middle-income countries [Executive summary]. Retrieved from https://www.intgovforum.org/cms/igf2016/uploads/proposal_background_paper/GSMARe port Executive-Summary NEWGRAYS-web3.pdf

Hendrikz, J., \& Aluko, F.R. (2013, October). Educational technology changes in Africa and its impact on ODL programmes delivery: the case of the University of Pretoria, South Africa. ICDE World Conference Proceedings, China.

Isaacs, S. (2007). ICT in education in South Africa [PDF]. Retrieved from http://www.infodev.org/infodev-files/resource/InfodevDocuments_429.pdf

Isaacs, S. (2012). Turning on mobile learning in Africa and the Middle East: illustrative initiatives and policy implications. Retrieved from http://www.oerafrica.org/system/files/9394/unescoturning-mobile-learning-africa-and-middle-east $\quad$ o.pdf?file=1\&type $=$ node\&id=9394\&force $=$

IST-Africa. (2012). Guide to ICT policy in IST-Africa partner countries [PDF]. Retrieved from http://www.ist-africa.org/home/files/IST-Africa_ICTPolicy 200412.pdf

Keating, C., \& Williams, M. (2006, August 23). Schools seek to ban 'addictive' Mxit [Blog post]. IOL News. Retrieved from http://www.iol.co.za/news/south-africa/schools-seek-to-banaddictivemxit-1.290620

Keegan, D. (2005). Mobile learning: The next generation of learning. Ireland: Distance Education International.

Kirkwood, A., \& Price, L. (2006). Adaptation for a changing environment: developing learning and teaching with information and communication technologies. The International Review of Research in Open and Distance Learning, 7(2). Retrieved from http://www.irrodl.org/index.php/irrodl/article/view/294/624

Kraut, R. (Ed.) (2013).United Nations Educational, Scientific and Cultural Organisation's (UNESCO) policy guidelines for mobile learning. Retrieved from http://unesdoc.unesco.org/images/0021/002196/219641E.pdf 
Laaser W. (2006). Virtual universities for African and Arab countries. Turkish Online Journal of Distance Education, 7(4). Retrieved from http://tojde.anadolu.edu.tr/tojde24/index.htm

Makoe, M. (2010). Exploring the use of MXit: A cellphone social network to facilitate learning in distance education. Open Learning, 25(3), 251-257. Retrieved from http://www.tandfonline.com/doi/pdf/10.1080/02680513.2010.512099?needAccess=true

Mayisela, T. (2013). The potential use of mobile technology: Enhancing accessibility and communication in a blended learning course. South African Journal of Education, 33(1), 118. Retrieved from http://www.sajournalofeducation.co.za/index.php/saje/article/view/629

Mims, C. (2012). A surprisingly long list of everything smartphones replaced [Blog post]. MIT Technology Review. Retrieved from https://www.technologyreview.com/s/428579/asurprisingly-long-list-of-everything-smartphones-replaced/

Mnisi, P. (2015). DBE's progress with ICT integration in schools. Retrieved from http://www.nstf.org.za/wp-content/uploads/2015/10/Progress.pdf

mobiThinking. (2015). Global mobile statistics 2012 Part C: Mobile marketing, advertising and messaging. Retrieved from https://mobiforge.com/research-analysis/global-mobilestatistics-2012-part-c-mobile-marketing-advertising-and-messaging

Muwanga, Z. (2009). Challenges to e-Learning in developing communities of Africa. Retrieved from http://ernwaca.org/panaf/spip.php?article676

Mwenje. T. (2014). Africa's average mobile penetration rate hits $75 \%$ as SADC dominates (Blog post). Retrieved from http://www.itwebafrica.com/mobile/339-africa/233317-africas-averagemobile-penetration-rate-hits-75

Ndlovu, N.S., \& Lawrence, D. (2012, September). The quality of ICT in South African classrooms. Paper presented at the Towards Carnegie III Conference, University of Cape Town, Cape Town.

Ngubeni, T. (2014). Mobile platforms shift learning models [Blog post]. Retrieved from http://www.itweb.co.za/index.php?option=com content\&view=article\&id=139164

Park, Y. (2014). A pedagogical framework for mobile learning: Categorising educational applications of mobile technologies into four types. In M. Ally \& A. Tsinakos (Eds.), Increasing access through mobile learning. Canada: Commonwealth of Learning.

Patton, M.Q. (1990). Qualitative evaluation and research methods. (2nd ed.). Newbury Park: Sage.

Qualman, E. (2016). 48 items that tech will replace this decade. Retrieved from https://www.clickz.com/48-items-that-technology-will-replace-this-decade/46973/

Reicher, S., \& Taylor, S. (2005). Similarities and differences between traditions. The Psychologist, 18(9), 547-549. 
Ryan, G.W., \& Bernard, H.R. (2003). Techniques to identify themes. Field Methods, 15(1), 85-109. doi: http://dx.doi.org/10.1177/1525822X02239569

Smith, M.S., \& Winthrop, R. (2012, January). A new face of education: bringing technology into the classroom in the developing world [Blog post]. Brookings. Retrieved from http://www.brookings.edu/research/papers/2012/o1/education-technology-winthrop

Tamukong, J.A. (2007). Analysis of information and communication technology policies in Africa. PanAf Edu Newsletter, 1(1), 4. Retrieved from http://www.ernwaca.org/panaf/IMG/pdf/panaf-newsletter-EN.pdf

Traxler, J. (2009). Current state of mobile learning. In M. Ally (Ed.), Mobile learning: Transforming the delivery of education and training. Edmonton: AU Press. Retrieved from http://www.aupress.ca/books/120155/ebook/99Z Mohamed Ally 2009-MobileLearning.pdf

Traxler, J. (2013). Potential of learning with mobiles in Africa [Blog post]. Retrieved from http://www.wise-qatar.org/content/prof-john-traxler-potential-learning-mobiles-africa

Trucano, M. (2009). Checking in with BridgeIT in Tanzania: Using mobile phones to support teachers. EduTech: A World Bank Blog on ICT Use in Education. Retrieved from http://blogs.worldbank.org/edutech/checking-in-with-bridgeit-in-tanzania

United Nations Children's Fund (UNICEF). (2012). South African mobile generation: study on South African young people on mobile. Retrieved from http://www.youthpolicy.org/library/wpcontent/uploads/library/2012 South_African_Mobile_Generation_Eng.pdf

United Nations Development Programme (UNDP). (2009). Capacity development: A UNDP primer [PDF]. Retrieved from http://www.undp.org/content/dam/aplaws/ publication/en/publications/capacity-development/capacity-development-a-undpprimer/CDG PrimerReport final web.pdf

United Nations Educational, Scientific and Cultural Organisation (UNESCO). (2011, December). UNESCO mobile learning week report [PDF]. Retrieved from http://www.unesco.org/ new/fileadmin/MULTIMEDIA/HQ/ED/ICT/pdf/UNESCO\%20MLW\%2oreport\%2ofinal\%20 19jan.pdf

United Nations Educational, Scientific and Cultural Organisation (UNESCO). (2012). Mobile learning for teachers in Africa and Middle East: Exploring the potential of mobile technologies to support teachers and improve practice. Paris: UNESCO.

United Nations Educational, Scientific and Cultural Organisation (UNESCO). (2012b). Mobile learning for teachers: Global themes. Paris: UNESCO.

Venkatesh, V. \& Bala, H. (2008). Technology acceptance model 3 and a research agenda on interventions. Decision Sciences, 39(2), 273-315. 
Viljoen, J., Du Preez C.S., \& Cook, A. (2005). Transforming learning through technology: the case of using SMSs to support distance education students in South Africa. Perspectives in Education, 23(4), 115-122.

Von Solms, S., \& Von Solms, R. (2014). Towards cyber safety education in primary schools in Africa. Proceedings of the Eighth International Symposium on Human Aspects of Information Security and Assurance (HAISA 2014). Retrieved from http://researchspace.csir.co.za/dspace/bitstream/10204/ 7875/1/Von\%20Solms 2014.pdf

Vosloo, S. (2013). Mobile learning at the Nigeria summit [Blog post]. Retrieved from https://stevevosloo.com/2013/03/20/mobile-learning-at-the-nigeria-summit/

Welch, T., \& Reed, Y. (Eds.). (2005). Designing and delivering distance education: quality criteria and case studies from South Africa. Johannesburg: NADEOSA.

\section{Athabasca \\ University}

(c) 